\title{
Family Size and the Distribution of Real Per Capita Income
}

\author{
By Edward P. Lazear and Robert T. MichaeL*
}

Per capita income is an important notion in economics. It is used as an explanatory variable with great frequency in theoretical and empirical analyses, and its size distribution is one of the long-standing topics of economic research. Moreover, it is a concept in which public concern is as deep and sustained as is professional interest. However, information about income is often obtained for household units instead of per capita units, or for only a subset of persons (for example, wage earners). This creates difficult problems with the measurement and, indeed, the concept of per capita income. The problems include: 1) within any household the apportionment of household income to members is not in general known; 2) comparison of household income per capita among households of different structures requires judgment about the relationship between real income and family size. Remarkably little study has been done on the first of these two issues.' This paper is another contribution to the vast literature which addresses the second issue.

This latter issue is usually characterized as one of determining the income equivalence among households of various sizes. These equivalence scales can either adjust

\footnotetext{
- University of Chicago and National Bureau of Economic Research (NBER), and Stanford University and NBER, respectively. This research was supported by grants to NBER from the Alfred P. Sloan Foundation and the Lilly Endowment. Sharon $R$. Scott provided excellent research assistance. We wish to acknowledge with thanks helpful suggestions from Gary S. Becker, Victor R. Fuchs, Kyle Johnson, Victoria Lazear, John H. Pencavel, Sharon R. Scott, and an anonymous referee. This is not an official NBER report as it has not been submitted to the Board of Directors for review.

'At a theoretical level Paul Samuelson and Gary Becker consider intrahousehold allocations, but empirically we know of few such studies. The estimates of costs of children by $A$. M. Henderson or T. J. Espenshade might be considered exceptions.
}

nominal income in different sized households into a common unit (i.e., into income in husband-wife-two-children equivalents) or adjust the number of household members into a common unit (i.e., into the number of full-time adult equivalents).

Many studies have estimated these equivalence scales since Engel in 1895 first estimated the newborn-baby equivalence among households of various sizes. One of two approaches to the estimation of equivalents has generally been used: 1) a revealed preference approach in which household size/structure variables are included in empirical demand studies and the estimated coefficients on these variables are used to infer equivalence; 2) a judgment of "experts" is relied upon to yield equivalence on the basis of some quasi-objective standard (such as daily nutritional needs) and a cost estimate of these items (food) for each household type is then expanded by some factor to approximate an equivalent income level. Most research favors the first approach (see S. J. Prais and Hendrik Houthakker; A. P. Barten; John Muellbauer) while the official U.S. poverty level equivalents are based on the Orshansky equivalence measures derived from a presumed nutritionally adequate economy food plan (see B. S. Mahoney). Our work also uses the first of these two approaches; it differs from many of the other studies not in basic concept but in its empirical strategy. While most studies build family composition effects into a relatively formal structural model of demand and impose considerable restriction in order to obtain an estimable system, we use a reducedform approach which requires much less of the data.

Professional and popular interest in per capita income is predicated on the assumption that income is an observable, mono- 
tonic index of economic well-being. One way to characterize the problem of family size equivalence is to ask about differences by family size in the transformation between income and well-being. We suggest in the model developed below that well-being (or utility) is derived from the service flows obtained from market and nonmarket goods and services; the service flows obtained from any particular bundle of market goods depends on the environment in which they are consumed including the quantities of nonmarket goods and services with which they are used. Nominal income adequately indexes the level of market expenditures and hence the bundle of market goods and services. However, its rate of transformation into service flows differs by family size and family structure, because these affect the environment and the nonmarket goods and services with which the market bundle is used. If in circumstance $A$, a particular market bundle which costs $\$ 1,000$ yields 20 units of service flow while in circumstance $B$ that same bundle yields 30 units of service flow, then in real terms the bundle in circumstance $B$ is equivalent to $\$ 1,500$ in units of circumstance $A$. If we know the different rates of transformation between the market goods and the service flows, we can infer levels of real income equivalence among households of various sizes and structures. In this paper we suggest and implement a way of inferring the differences in these rates of transformation from household spending patterns. We calculate implicit deflators by which nominal income in one family size can be converted to its equivalence in some other family size.

The logic of our empirical strategy is as follows: We take as a numeraire an adult living alone in a single person household. For a husband-wife (two-person) household we observe their actual expenditure on some good (say, clothing) and we independently estimate the expenditure these two persons would have made in total had they lived separately in single person households. We contend that the change in their expenditure on clothing. in those two circumstances reflects their response to a change in the price of the service flow from clothing, a price change which resulted from the changed environment in which the clothing is used. The organization of the household, the nonmarket goods and time with which the market goods are used, the scale of activities, etc. differ in the two-person household (circumstance $B$ ) from the two one-person households (circumstance $\dot{A}$ ), so the service flow from a given bundle of goods (clothing) differs in these two circumstances. Thus at constant market prices the service flow price changes with the circumstance. From knowledge of uncompensated market-price elasticities and our estimates of changes in expenditures from circumstance $A$ (living in single person household) to circumstance $B$ (living in a two-person, husband-wife household) we can infer what price change the couple acts as if it experienced in going from $A$ to $B$. We estimate this price change for each of several consumption categories which exhaust total consumption. Combining these price changes into a composite index we have a deflator by which nominal income in two-person, husband-wife families can be converted into real income in single person household (numeraire) units. This same procedure can be used for any other family structure as well. We have used this technique to convert several common family structures-two-person, husband-wife families; three-petson, husband-wife-child families; four-and five-person, husband-wife, two and threechildren families - into single person equivalents.

Before discussing the model in more detail it is appropriate to discuss why we expect the rate of transformation of dollars into service units to differ by family structure. We suggest three mechanisms:

1) Family goods: There are certain public goods within the family or household, goods whose consumption by one member does not diminish their availability to other members. Examples abound: electric light in a room, the beauty of art work on the wall, the security provided by a locked bolt on the door, etc. Here, if $\$ 5$ provides the man with a securely locked door and $\$ 5$ provides the woman with the same living separately, then together its price is to each 
$\$ 2.50$, a reduction in the price of the service flow resulting from the change in household size.

2) Scale economies: Examples include quantity discounts on larger purchases of perishables; less wastage per unit (for example, if the last teaspoon of milk is thrown out with each purchased carton, the larger the carton the smaller the percentage wasted); reduced excess capacity due to indivisibility (a telephone, TV, shower, refrigerator space, etc. is often idle and the utilization rate can be raised by increases in family size).

3) Complementarity in the use of goods: Specialization in household duties can result in greater service flow per dollar spent-if goods are combined with time in a productive way, then the more time per unit of good, the higher the marginal product of the good. Money income may not rise proportionately with family size because additional family members supply less time to the labor market. So the ratio of nonmarket time to the quantity of purchased goods may rise. This in turn should raise the flow of services per dollar spent on goods.

For reasons of family (public) goods, scale economies, and division of labor, we expect the rate of transformation between market purchases and real service flows to vary by family size. While most of the examples given suggest a rising level of services per unit of market purchase as family size increases, there may be offsets as well (such as negative externalities from one person's smoking, longer travel distance to work or play for one or for all family members as a result of living in the collectively optimal location). ${ }^{2}$ Neither the logic nor the empirical implementation constrains the direction of effects of family size on the rates of transformation or therefore on real income.

\section{The Model}

Consider an individual with demand for a particular service flow, $S_{1}$. That service flow

\footnotetext{
${ }^{2} \mathrm{Jacob}$ Mincer has found that joint locational choice tends to reduce the wages earned as both workers trade their own earnings for spouse earnings.
}

is obtained by the individual using a purchased market input denoted $X_{1}$. As an example, the individual may obtain entertainment services as a flow from his purchased market input, a TV set. The rate of transformation between $X_{1}$ and $S_{1}$ will in general not be independent of the environment in which the individual interacts with $X$ in securing $S$. For example, the household size in which the individual resides may affect the rate at which $X$ yields units of $S$. If there are two household members instead of one, a TV set may yield more or less units of entertainment services to the individual (i.e., more if the two share the TV or discuss the show and less if the second member interferes with the viewing). As command over resources in service flow units ( $S$ s) rather than market goods units $(X \mathrm{~s})$ constitutes a measure of real income, it is appropriate to adjust for these differences in rate of transformation when comparing income levels among households of different sizes.

Suppose the individual's demand for $S_{1}$ is

$$
S_{1}=d\left(P_{s 1}, Y\right)
$$

where $P_{s 1}$ is the unit price of $S_{1}$ and $Y$ is the individual's nominal money income. Let $\alpha_{1}$ be the number of units of $S_{1}$ produced per unit of market good $X_{1}$ :

$$
\alpha_{1} \equiv S_{1} / X_{1}
$$

Note that $\alpha_{1}$ is thus the average product of $X_{1}$ where $X_{1}$ is analogous to capital and $S_{1}$ is analogous to output. Nonmarket time (analogous to labor input) is suppressed in our model, but if nonmarket time is used with $X_{1}$ in the production of $S_{1}$, then an increase in time per unit of $X_{1}$ would raise the average product of $X_{1}$, implying a higher $\alpha_{1}$. Then

$$
P_{s 1}=P_{1} / \alpha_{1}
$$

where $P_{1}$ is the unit price of the market $\operatorname{good} X_{1}$. Thus

$$
S_{1}=d\left(\frac{P_{1}}{\alpha_{1}}, Y\right) \equiv g\left(P_{1}, Y\right)
$$


with $\alpha_{1}$ fixed to the individual, given his environment. From equations (2) and (4) the derived demand for $X_{1}$ would be

$$
X_{1}=g\left(P_{1}, Y\right) / \alpha_{1} \equiv h\left(P_{1}, Y\right)
$$

If for any reason $\alpha_{1}$ were changed, the demand for $S_{1}$ would change and the derived demand for $X_{1}$ might be affected. For example, suppose a change in the individual's household environment altered the ratio of $S_{1} / X_{1}$ from $\alpha_{1}$ to, say, $\alpha_{1}\left(1+J_{1}\right)$. If $J_{1}>0$, the effective price of a unit of $S_{1}$ would fall (see equation (3)), and accordingly its quantity demanded would rise. Equation (4) would be

$$
S_{1}=g\left(\frac{P_{1}}{1+J_{1}}, Y\right)
$$

The derived demand for $X_{1}$, however, need not rise: as $X_{1}=S_{1} / \alpha_{1}(1+J)$,

$$
X_{1}=h\left(\frac{P_{1}}{1+J_{1}}, Y\right) /\left(1+J_{1}\right)
$$

Although the fall in the price of $P_{s 1}$ assures a rise in the numerator, the denominator offsets this rise, reflecting the additional units of $S_{1}$ obtained per unit of $X_{1}$. Only if the demand for $S_{1}$ is price elastic will the derived demand for $X_{1}$ rise with an increase in $J_{1}{ }^{3}{ }^{3}$

Taking some particular environment as a numeraire one can use equations (5) and (5') to infer the value of $J_{1}$ which converts dollar values in the second environment into units

$$
\begin{aligned}
& 3 \\
& X=d\left(P_{s i}, Y\right) / \alpha_{1}\left(1+J_{1}\right) \\
& \text { so } \\
& \frac{\partial X}{\partial J}=\frac{1}{\alpha(1+J)} \frac{\partial d\left(P_{s i}, Y\right)}{\partial J}-\frac{d}{\alpha(1+J)^{2}} \\
& =-\left(\frac{X}{1+J}\right)\left(e_{S P_{s}}+1\right) \\
& \text { or } \quad \varepsilon_{X J}=-\left(\frac{J}{1+J}\right)\left(\varepsilon_{S P_{s}}+1\right) \\
& \text { hence } \quad \varepsilon_{X J} \geq 0 \text { as }\left|\varepsilon_{S P s}\right| \geq 1
\end{aligned}
$$

of the numeraire. The term $J$ reflects the percentage by which the price of the item in service units changes as the environment changes from circumstance $A$ (the numeraire) to circumstance $B$. The nominal dollars spent on $X_{1}$ in circumstance $B$ is the equivalent in real $\left(S_{1}\right)$ terms to $\left(1+J_{1}\right)$ times that expenditure in the units of the numeraire. If, for instance, equation (5) reflects the demand for $X_{1}$ for a person living in a household of size 1.0, then equations (5) and $\left(5^{\prime}\right)$ yield estimable relationships from which we can infer the $J_{1}$ relevant to a person living in a household of size 2.0.

Notice that the role of leisure (nonmarket time), although suppressed, is not ignored. To the extent leisure is used in conjunction with market goods its effects are captured: $\alpha_{i}$ is the average product of $X_{i}$ in the production of $S_{i}$, and $\left(1+J_{i}\right)$ reflects the change in that average product when an additional household member is added, so a change in the amount of leisure time used per unit of $X_{i}$ will be reflected in the $J_{i}$. If leisure time produced a distinct service $S_{l}$ by itself, one might add $S_{l}$ to the set of items studied. We chose not to take this approach for three reasons. First, it seems intuitively unlikely that leisure produces any substantial amount of service without the use of consumer goods. Indeed many "leisure activities" require considerable market goods and services. But if leisure time is always coupled with goods, then the $J_{i}$ corresponding to changes in the average product of goods will reflect the impact of any change in leisure time.

Second, since most policy decisions are based on a market goods measure of income rather than a "full-income" concept, it is useful to put our equivalence scales in a form consistent with measured income. Third, since our data do not report hours worked, it is not feasible to obtain information on leisure time in our sample; we are therefore unable to treat leisure time as a distinct service item even if we thought that desirable. In the following paragraphs we set out an explicit set of equations from which we can estimate these $J$ s from survey data on expenditure and income. 
We parameterize equation (5) for an individual $m:^{4}$

$$
X_{1 m}=a_{0}+a_{1} P_{1}+\ldots+a_{n} P_{n}+b_{1} Y_{m}
$$

where $P_{i}$ is the price of the $i$ th good and $Y_{m}$ is the person's nominal income. Similarly, assume that another individual, denoted $f$, has the same demand function and faces the same market prices,

$$
X_{1 f}=a_{0}+a_{1} P_{1}+\ldots+a_{n} P_{n}+b_{1} Y_{f}
$$

$X_{1 m}$ and $X_{1 f}$ refer to the amount of $X_{1}$ demanded by the two individuals separately if each lives in a household of size 1.0. Thus, the total amount demanded by the two as single individuals is

$$
\begin{aligned}
\left(X_{1 m}+X_{1 f}\right)= & 2 a_{0}+2 a_{1} P_{1}+\ldots \\
& +2 a_{n} P_{n}+b_{1}\left(Y_{m}+Y_{f}\right)
\end{aligned}
$$

If the two individuals were to pool resources and live in a single household of size 2 , and if as a result there is an effect on the rate of transformation between $X_{1}$ and $S_{1}$, the effective price of $S_{1}$ would be altered. The price would change from $P_{1} / \alpha_{1}$ to $P_{1} / \alpha_{1}\left(1+J_{1}\right)$ as described above and likewise for all other consumption items $S_{2} \cdots S_{n}$. Thus the couple's demand for $X_{1}$ would be (from equation (5)):

$$
\begin{aligned}
& X_{1 m f}=\left[2 a_{0}+2 a_{1}\left(\frac{P_{1}}{1+J_{1}}\right)+\ldots\right. \\
& \left.+2 a_{n}\left(\frac{P_{n}}{1+J_{n}}\right)+b_{1}\left(Y_{m f}\right)\right] /\left(1+J_{1}\right)
\end{aligned}
$$

While equation (8) represents the demand for $X_{1}$ by these two individuals when they live separately, (9) represents their demand when they live together. Forming the dif-

\footnotetext{
Equation (6) should be thought of as an approximation of the true demand curve. As such, it does not have the normal Slutzky properties (except at the mean). We believe, however, that the linear form is much more robust and much less affected by the significant errors-in-variables problem that plagues analyses of this type. In empirical implementation, it behaved more reasonably than the $\log$ form often used in these studies.
}

ference, equation (8) minus equation (9):

$$
\begin{aligned}
& \text { (10) }\left(X_{\mathrm{I} m}+X_{1 f}\right)-X_{1 m f}\left(1+J_{1}\right) \\
& =2 a_{1} P_{1}\left(1-\frac{1}{1+J_{1}}\right)+\ldots \\
& +2 a_{n} P_{n}\left(1-\frac{1}{1+J_{n}}\right)+b_{1}\left(Y_{m}+Y_{f}-Y_{m f}\right)
\end{aligned}
$$

which can be written as

$$
\begin{aligned}
& \Delta P X_{1} \equiv \frac{P_{1}\left(X_{1 m}+X_{1 f}\right)}{P_{1} X_{1 m f}}=\left(1+J_{1}\right) \\
& +2 \sum_{i=1}^{n} \eta_{1 i}\left(1-\frac{1}{1+J_{i}}\right)+\eta_{X 1, \gamma}(\Delta Y-1)
\end{aligned}
$$

The left-hand side is the ratio of the expenditure on $X_{1}$ the two individuals would make if living alone to the expenditure they make if living as a pair; the $\eta_{1 i}$ are uncompensated own- and cross-price elasticities, $\eta_{X 1, Y}$ is the income elasticity, and $\Delta Y=\left(Y_{m}\right.$ $\left.+Y_{f}\right) / Y_{m f}$ An equation comparable to equation (11) can be set out for each of the $n$ market goods.

Before we consider estimation of equation (11), note that if the $J_{1}, J_{2}, \ldots, J_{n}$ for each market good were calculated we could estimate equivalence between nominal income in the numeraire, circumstance $A$ (living alone) and nominal income in circumstance $B$ (living in a household of size 2). If $Y_{m f}$ is the observed nominal income of the couple and $Y_{m f}^{*}$ is its real income equivalent in single person household units,

$$
Y_{m f}^{*}=Y_{m f}\left(\sum_{i=1}^{n}\left(1+J_{i}\right) w_{i}\right) \equiv Y_{m f}(1+J)
$$

where the $w_{i}$ is the expenditure weight of item $i$ in the couple's consumption bundle, and $J$ (unsubscripted) is the weighted average of the $J_{i}$. (The choice of base for the weights introduces the classic index number problem.) If, for example, the couple experienced a 5 percent increase in the flow of $S_{i}$ from $X_{i}$ for all $i$ then $J_{i}=J=.05$, and a nominal income of say $\$ 5,000$ for the couple 
would be the equivalent of $\$ 5,000(1.05)=$ $\$ 5,250$ income for the couple in real $(S)$ units of single person income.

The system of $n$ equations of which equation (11) is representative has for each household several variables or parameters: $P_{i} X_{i m f} ; P_{i}\left(X_{i m}+X_{i j}\right) ; \Delta Y ; \eta_{X i, Y} ; \eta_{i j} ; J_{i}$. With known values for the first five of these sets of variables, we can solve for the $J_{i}$. The first set (of which there are $n$ elements) is simply the actual expenditure on $X_{i}$ by the couple. It can be obtained from survey data for persons living in households of size 2.0. The second set (of which there are $n$ elements) reflects the total expenditure on each item by the two persons if they lived separately in households of size 1.0. That counterfactual expenditure can be estimated from survey data on like individuals living in households of sizes 1 and 2 (as described in detail below). The third variable includes the couple's actual nominal income $Y_{m f}$ and the counterfactual income the two would have received if they were living as two separate individuals. The former is available in survey data and the latter is estimable from survey data on like individuals living in households of sizes 1 and 2 (also described below). The fourth and fifth set of variables include the $n$ income elasticities and $n$ own-price elasticities and the $n(n-1)$ cross-price elasticities of demand. These should be available in the economic literature on empirical demand systems. With these five sets of variables known, the system of equations reduces to $n$ equations in $n$ unknowns-the $n$ values of $J_{i}$. The system can be used to estimate the $J_{i} \mathrm{~s}$ which reflect the price changes couples act as if they experience in going from households of size 1 to households of size 2 .

In principle, equation (11) could be estimated for each two person husband-wife couple separately, but as the values of $P_{i}\left(X_{i m}+X_{i f}\right)$ and $\left(Y_{m}+Y_{j}\right)$ are estimated by regression and subject to nonnegligent estimation error, we have chosen instead to use a measure of the average household values of each as a more reliable estimate.

\footnotetext{
${ }^{5}$ There are two methods of estimating $J$ for the two-person families: use each of the $k$ couples' $\triangle P X$ to obtain an estimate of $J_{i k}$ and then average across the $k$
}

In particular, after estimating $P_{i}\left(X_{i m}+X_{i j}\right)$ for each couple in our data set based on their characteristics, we form a ratio of that estimate for good $i$ to their actual expenditure $P_{i} X_{i m f}$ and then select the median value of that ratio, $\triangle P X_{i}$, across all two-person husband-wife households. ${ }^{6}$ A similar procedure yields a separate $\triangle P X$ for each market good and an estimated $\Delta Y$. In addition, an analogous procedure yields independent estimates of $\triangle P X$ for all goods and of $\Delta Y$ for households of other sizes and structures as well. These procedures and the estimated price changes and income equivalents are discussed in the following section. ${ }^{7}$ To reiterate, these values are used in equation (11) to permit us to solve for the $J_{i}$.

\section{Empirical Implementation}

The data set used in our study is the 1960-61 BLS Consumer Expenditure Survey of 13 thousand households. Six expenditure groups are used: food; clothing; trans-

couples to obtain $J_{i}$; use the median $\Delta P X_{i}$ and $\Delta Y$ for the $k$ couples and then estimate $J_{i}$ from that median. We used the second method. The first has several problems: the value of $J$ is quite sensitive to $\Delta P X$ and in some cases $J$ will not be a real number. So measurement error is much more likely to affect each $J_{i k}$ computed separately than it is if $J_{i}$ is computed from the relatively robust estimate of the median $\Delta P X$.

'The median rather than the mean of the estimated ratios is used since this ratio has in its denominator a stochastic variable assumed to be distributed normally, and thus the ratio has a Cauchy distribution for which the moments do not exist. The expectation of estimators obtained using, say, the mean will not exist. As is standard in such cases we assume that the median of the error is zero across all observations and so minimizing the sum of absolute errors is accomplished by use of the median value of the ratio.

${ }^{7}$ Barten proposed a similar scheme. He suggests $U=$ $u\left(x_{1}, \ldots, x_{n}\right)$ where $x_{i}=q_{i} / m_{i}$ with $q$ the quantity of the purchased good, and $m_{i}=m_{i}\left(b_{1}, \ldots, b_{f}\right)$ where $b$ is the number of family members of a given type and $m_{i}$ an index of the composition of the family, and shows that "a change in the composition of the family can be translated into terms of a pseudo-price change" (p. 282). His structure is obviously similar to ours, but the suggested research strategy differs. Barten argues that cross-sectional data can be used to estimate price elasticities: using differences in $m_{i}$ among households as analogues of differences in market prices, differences in spending patterns can yield estimates of "price" elasticities. We suggest, instead, using independent estimates of price elasticities and the actual (estimated) differences in expenditures to infer the changes in prices. 
Table 1-Estmates of Expenditure Shifts, Implied Price Changes, and Real Income Deflators for Familes of Size 2-5; fRom 1960-61 BLS, CES

\begin{tabular}{|c|c|c|c|c|c|c|c|c|}
\hline \multirow{2}{*}{$\begin{array}{l}\text { Expenditure } \\
\text { Item }\end{array}$} & \multicolumn{2}{|c|}{ 2-Person Families ${ }^{\mathrm{a}}$} & \multicolumn{2}{|c|}{ 3-Person Families ${ }^{b}$} & \multicolumn{2}{|c|}{ 4-Person Families ${ }^{c}$} & \multicolumn{2}{|c|}{ 5-Person Families ${ }^{d}$} \\
\hline & $\Delta P X_{i}$ & $J_{i}$ & $\Delta P X_{i}$ & $J_{i}$ & $\Delta P X_{i}$ & $J_{i}$ & $\Delta P X_{i}$ & $J_{1}$ \\
\hline Food & 1.35 & 0.995 & 1.65 & 1.397 & 1.76 & 1.665 & 1.88 & 1.835 \\
\hline Clothing & 1.31 & 0.848 & 1.97 & 1.676 & 2.20 & 2.083 & 2.49 & 2.431 \\
\hline Transportation & 1.16 & 0.843 & 1.78 & 1.668 & 1.99 & 2.108 & 2.26 & 2.457 \\
\hline Shelter & 1.33 & 0.873 & 1.20 & 0.708 & 1.31 & 1.040 & 1.34 & 1.118 \\
\hline Goods & 1.09 & 0.944 & 1.63 & 1.695 & 1.99 & 2.366 & 2.33 & 2.684 \\
\hline Service & 1.12 & 0.677 & 1.19 & 0.800 & 1.21 & 1.041 & 1.34 & 1.253 \\
\hline \multicolumn{9}{|l|}{$\begin{array}{l}J: \text { Weighted Average } \\
\text { (group }\end{array}$} \\
\hline specific wts.) & & 0.886 & & 1.338 & & 1.728 & & 1.961 \\
\hline \multicolumn{9}{|l|}{$\begin{array}{l}\text { Per capita real income } \\
\text { equivalent of } \$ 10,000 \\
\text { nominal family income }\end{array}$} \\
\hline $\begin{array}{c}(Y(1+J) / j) \\
\text { Marginal Person }\end{array}$ & & $\$ 9,428$ & & $\$ 7,795$ & & $\$ 6,819$ & & $\$ 5,921$ \\
\hline \multicolumn{9}{|l|}{ Marginal Person } \\
\hline${ }_{n}^{j /\left(1+J_{j}\right)-(j-1) /\left(1+J_{j-1}\right)}$ & & .061 & & .222 & & .184 & & .222 \\
\hline$n$ & \multicolumn{2}{|c|}{2,918} & \multicolumn{2}{|c|}{1,162} & \multicolumn{2}{|c|}{1,598} & \multicolumn{2}{|c|}{1,061} \\
\hline
\end{tabular}

Husband and wife.

bHusband, wife, and child.

'Husband, wife, and two children.

dHusband, wife, and three children.

portation; shelter; other goods; other services. The six groups exhaust total current consumption expenditure. ${ }^{8}$ For households of size 1.0 (sample size 598) a reduced-form expenditure demand equation is estimated for each of these six items, using as explanatory variables sex, year (1960 or 1961), region, city size, race, age, and education. This equation is used to estimate for largersized households the expenditures each family member would have made had he or she lived separately in a household of size 1.0.

Consider the two-person, husband-wife families. We estimate, using these estimated demand equations and the husband's characteristics (education, age, race, city size, region...), the yearly expenditure the husband would have made on food, clothing, etc. had he lived alone. Likewise using that equation and these characteristics we estimate the yearly expenditure the wife would have made if she lived alone. ${ }^{9}$ The

\footnotetext{
${ }^{8}$ The Appendix contains details of the data set and estimators described in the text.

The characteristics for the wives in this data set are not generally available so we had to use her husband's age, race, and education.
}

sum of these estimated expenditures which he and she would have made if each lived separately constitutes our estimate of $P_{i}\left(X_{i m}\right.$ $+X_{i j}$ ) for item $i$. That estimate is divided by the couple's actual yearly expenditure on $i$, $P_{i} X_{i m f}$, and that ratio $\Delta P X_{i}$ for item $i=$ $1, \ldots, 6$ is calculated for each of the 2,918 two-person husband-wife families. The median value of the distribution of each of those ratios is used as the value of $\Delta P X_{i}$ in the left-hand side of equation (11) for estimating the $J_{i}$ for two-person households. The estimated values of $\triangle P X_{i}$ are shown in the first column of Table 1. All exceed unity, implying that the predicted expenditure by the couple living separately as two households exceeds the couple's actual expenditure (by amounts ranging from 9 percent for other "goods" to 35 percent for "food" which includes restaurant expenses).

To obtain an estimate of $\Delta Y$ a similar procedure was employed. We estimated from the single men and women in our sample separate income functions based on the individual's personal characteristics (year, schooling level, age, race, city size, and region). We then used these equations to estimate for the husband and for the wife 
separately in each of our two-person families the income each pair might have received had he and she remained single (behaving as singles do in terms of labor supply and nonwage income generation). With that estimate of $Y_{m}+Y_{f}$ and the couple's actual income $Y_{m f}$, we formed the ratio $\Delta Y_{k}$ for each of the $k=2,918$ couples and determined the median value $\Delta Y$. Its value was 1.2362.

Equation (11) also requires uncompensated price elasticities of the six market goods. One would think that the vast literature on demand systems in the past two decades would have produced a consensus about their magnitudes under various conditions. We have not found that consensus and have chosen to use elasticity estimates derived from Michael Abbott and Orley Ashenfelter's study. We selected the set of elasticity estimates from the Stone-Geary linear expenditure system, evaluated at 1960 prices. These elasticities are shown in Table $2 .^{10}$ Ideally, we require elasticity estimates derived from household-size-specific expenditure behavior, not estimates derived from observations across households of various sizes. One justification for using the Abbott and Ashenfelter estimates is that average household size changed little over the time span covered by their time-series study, by less than 1.0 person over the entire 38 -year period and by less than 0.1 person from 1950 to the end of their time-series, 1967. So we feel these estimates are accept-

${ }^{10}$ The Abbott-Ashenfelter system estimated coefficients for food, clothing, shelter, and other services which we used directly. Our other two items are composites, and we simply took appropriately weighted averages of the separate elasticity estimates. Our transportation item is composed of 37.6 percent auto purchases and 62.4 percent auto operations and public transportation, so we used a weighted average of "durables" (which contained auto purchases) and "transportation services." Likewise, our "goods" item contains, for couples, 42.8 percent house furnishings and equipment and 57.2 percent tobacco, recreational expenses, reading material, and motels, so we used a weighted average of "durables" and "other nondurables" (tobacco, oil and gas, other miscellaneous nondurables). The Abbott-Ashenfelter system also includes a demand curve for leisure time. We adjusted the discretionary income slope coefficients on the expenditure items to remove discretionary leisure from the demand system. ably close to the conceptually appropriate elasticities.

Given these price and income elasticities and the estimates of $\Delta P X_{i}$ and $\Delta Y$, equation (11) can be written for each of the six consumption items yielding a system of six equations in six unknowns, $J_{1}, \ldots, J_{6}$. As a set of quadratic equations there are two roots for each $J_{i}$ and it can be shown that each pair contains a positive and a negative root. ${ }^{11}$

Economic theory tells us which of the two roots is relevant: from equations (2) and (3) we know $P_{s i} S_{i}=P_{i} X_{i}$ for any $\alpha_{i}$, so if $\Delta P X_{i}$ $>1.0$, implying expenditure on $X_{i}$ is lower in the two-person household than in the two single person households, we know their expenditure in terms of $S$ is also lower. If the price elasticity $\left|\eta_{i i}\right|<1.0$, we know that price and expenditure move in the same direction

$$
\begin{aligned}
& { }^{11} \text { Equation (11) for item } 1 \text { can be written as } \\
& \begin{array}{l}
\left(J_{1}\right)^{2}+\left[2+2 \eta_{11}-\Delta P X_{1}+\eta_{X i, Y}(\Delta Y-1)\right. \\
\left.\qquad \sum_{i=2}^{n}\left(2 \eta_{1 i} \frac{J_{i}}{1+J_{i}}\right)\right] J_{1} \\
+\left[1-\Delta P X_{1}+\eta_{X 1, Y}(\Delta Y-1)+\sum_{i=2}^{n}\left(2 \eta_{1 i} \frac{J_{i}}{1+J_{i}}\right)\right]=0
\end{array}
\end{aligned}
$$

a quadratic equation with two roots for $J_{1}$ for giveri values of $J_{2}, \ldots, J_{6}$. Solving the six-equation set of quadratic equations simultaneously yields the consistent set of two roots for each of the six J's. From the quadratic equation with roots

$$
r_{1}, r_{2}=\frac{-b \pm \sqrt{b^{2}-4 a c}}{2 a}
$$

we know $\left(r_{1}\right)\left(r_{2}\right)=c / a$. In the above quadratic equation $a=1$, and $c$ equals the second, long term in brackets. For practically every item $(k)$ in our study the sign of $1-\Delta P X_{k}+\eta_{X k, Y}(\Delta Y-1)<0$ and since $\eta_{k i}<0$ and we know $J_{i}>0$ the final expression in $c$ is also negative-hence $c<0$ and thus $c / a<0$ implying the product $\left(r_{1}\right)\left(r_{2}\right)<0$ which implies that one root must be negative and one positive. If each of the six $J$ s has one positive and one negative root, and we know from economic theory that a positive $J$ is necessary in light of our estimated $\triangle P X_{i}$ and $\eta_{i i}$, then only one set of the many possible combinations of roots to the six-equation system is relevant: the one set of six positive roots. (The one remaining point to be made is that for those few cases in our study for which $1-\Delta P X_{k}+\eta_{X k, Y}(\Delta Y$ $-1)>0$ the final expression is many-fold larger in absolute value and negative in sign, hence for these cases as well $c<0$ and our proof holds.) 
Table 2 -Estmated Price and Income Elasticities $\eta_{i j}$ for Six Market Goods Evaluated at 1960 Prices

\begin{tabular}{lccccccr}
\hline \hline$i$ & $j=$ Food & Clothing & Transport & Shelter & Goods & Services & Income \\
\hline Food & -.631 & -.034 & -.013 & -.085 & -.030 & -.057 & .766 \\
Clothing & -.093 & -.507 & -.014 & -.092 & -.032 & -.062 & .828 \\
Transport & -.124 & -.049 & -.598 & -.122 & -.048 & -.083 & 1.101 \\
Shelter & -.100 & -.040 & -.015 & -.555 & -.035 & -.066 & .886 \\
Goods & -.149 & -.059 & -.023 & -.146 & -.748 & -.099 & 1.318 \\
Services & -.112 & -.044 & -.016 & -.110 & -.039 & -.602 & .994 \\
\hline
\end{tabular}

Source: Derived from Abbott and Ashenfelter estimates from augmented Stone-Geary linear expenditure system.

along the demand curve. Thus, if $\left|\eta_{i i}\right|<1.0$ and $\Delta P X_{i}>1.0$, we can infer that the price $\left(P_{s i}\right)$ the couple faces is lower than the price the two as single individuals face: that is, the price fell from $P_{X i} / \alpha_{i}$ to $P_{X i} / \alpha_{i}\left(1+J_{i}\right)$. Hence we know

$$
\frac{P_{X i}}{\alpha_{i}}>\frac{P_{X_{i}}}{\alpha_{i}\left(1+J_{i}\right)} \rightarrow\left(1+J_{i}\right)>1 \rightarrow J_{i}>0
$$

If instead $\left|\eta_{i i}\right|>1.0$, the same logic implies that if $\Delta P X_{i}>1.0$, then $J_{i}<0$. Or, of course, if the expenditure rose, $\Delta P X_{i}<1.0$, then if $\left|\eta_{i i}\right|<1.0, J_{i}<0$. The four logical possibilities for the sign of $J_{i}$ are:

\begin{tabular}{|c|c|c|}
\hline \multirow{2}{*}{$\begin{array}{l}\text { Uncompensated } \\
\text { Price Elasticity } \\
\qquad\left|\eta_{u}\right|\end{array}$} & \multicolumn{2}{|c|}{$\Delta P X_{i}$} \\
\hline & $>1.0$ & $<1.0^{12}$ \\
\hline $\begin{array}{l}<1.0 \\
>1.0\end{array}$ & $\begin{array}{l}\text { positive } \\
\text { nega tive }\end{array}$ & $\begin{array}{l}\text { negative } \\
\text { positive }\end{array}$ \\
\hline
\end{tabular}

As all the own-price elasticities estimated from Abbott and Ashenfelter are inelastic, and all the $\triangle P X_{i}$ shown in the first column of Table 1 happen to be greater than 1.0, all the relevant $J_{\mathrm{s}}$ are positive, in this case. ${ }^{13}$

The second column of Table 1 shows the implied value of $J_{i}$ for two-person households. Weighting by the average expenditure shares of these six items for the 2,918 cou-

\footnotetext{
${ }^{12}$ Real roots may not exist.

${ }^{13}$ It may be well to stress that neither of these conditions (inelasticity nor decline in expenditure) is a logical or computational necessity. In fact, in preliminary work we used other estimates of elasticities, one of which exceeded 1.0, and in other preliminary work we did estimate a few $\Delta P X_{i}$ 's which were $<1.0$. A different level of commodity aggregation would surely yield such estimates (for example, smaller aggregates will have more substitutes so more elastic demand curves). The procedure used here can accomodate these differences easily.
}

ples, the average $J$ is also shown. As $J=$ 0.886 , on average the prices of $S$ faced by couples are estimated to be only 53 percent $(1 /(1+J))$ as high as the prices of $S$ faced by single person households. The relative prices also are affected: the price of market "services" falls least (to 60 percent of its single person level $(1 / 1+0.677))$, while the price of services from "food" falls most (to 50 percent of its single personal level $1 /(1+$ $0.995)$ ). The largest gains from the change in circumstance (marrying, sharing duties, achieving economies of scale and joint consumption advantages) are in food, goods and shelter; the smallest gains are in the purchase of market services, comprised primarily of medical care and personal care expenditures. We view this set of estimated price changes as intuitively plausible. Its overall magnitude is large and that we discuss below.

Using equation (12) it is a simple matter to convert nominal family income of a couple into its single person equivalent for the two individuals: if the couple's observed nominal family income is $\$ 10,000$, the "real" income is $\$ 10,000(1+J)=\$ 18,856$, as per capita, the husband and wife realize $\$ 18,856$ $+2=\$ 9,428$, as indicated in Table 1 . That is, a couple with observed family income of $\$ 10,000$ is estimated to have the same per capita income as a single person with $\$ 9,428$. The "economies of scale" are substantial, although these gains are not simply scale effects but also include the effects of complementarity in time and money use and the public (family) goods effects. As mentioned earlier, we can convert dollars into common units per person or convert persons into full-time full-person equivalents, and doing so in this case yields 1.061 as the full-person 
TABle 3-Nominal and Real Family Income, $Y$ and $Y^{*}$, By Family Size (MeAn (STANDARD DEVIATION) AND MEDIaN)

\begin{tabular}{|c|c|c|c|c|c|c|}
\hline & \multicolumn{6}{|c|}{ Family size } \\
\hline & 1 & 2 & 3 & 4 & 5 & Total \\
\hline & & & Mean (sta & deviation & & \\
\hline \multicolumn{7}{|l|}{ Family income } \\
\hline Nominal $(Y)$ & $\begin{array}{l}\$ 3539 . \\
(2353 .)\end{array}$ & $\begin{array}{l}\$ 5099 . \\
(3955 .)\end{array}$ & $\begin{array}{l}\$ 6141 . \\
(3135 .)\end{array}$ & $\begin{array}{l}\$ 6990 . \\
(4143 .)\end{array}$ & $\begin{array}{l}\$ 7221 . \\
(4711 .)\end{array}$ & $\begin{array}{l}\$ 5856 . \\
(4049 .)\end{array}$ \\
\hline Real $\left(Y^{*}\right)$ & $\begin{array}{l}3539 . \\
(2353 .)\end{array}$ & $\begin{array}{l}9611 . \\
(7439 .)\end{array}$ & $\begin{array}{l}14382 . \\
(7508 .)\end{array}$ & $\begin{array}{l}18903 . \\
(9858 .)\end{array}$ & $\begin{array}{c}21203 . \\
(12330 .)\end{array}$ & $\begin{array}{c}13572 . \\
(10181 .)\end{array}$ \\
\hline \multicolumn{7}{|l|}{ Per capita income } \\
\hline Nominal $(Y)$ & $\begin{array}{c}3539 . \\
(2353 .)\end{array}$ & $\begin{array}{c}2550 . \\
(1977 .)\end{array}$ & $\begin{array}{l}2047 . \\
(1045 .)\end{array}$ & $\begin{array}{l}1748 . \\
(1036 .)\end{array}$ & $\begin{array}{l}1444 . \\
(942 .)\end{array}$ & $\begin{array}{l}2216 . \\
(1693 .)\end{array}$ \\
\hline \multirow[t]{2}{*}{$\operatorname{Real}\left(Y^{*}\right)$} & $\begin{array}{c}3539 . \\
(2353 .)\end{array}$ & $\begin{array}{l}4806 . \\
(3719 .)\end{array}$ & $\begin{array}{l}4794 . \\
\text { (2503.) }\end{array}$ & $\begin{array}{l}4726 . \\
(2465 .)\end{array}$ & $\begin{array}{c}4241 . \\
(2466 .)\end{array}$ & $\begin{array}{l}4601 . \\
(3046 .)\end{array}$ \\
\hline & \multicolumn{6}{|c|}{ Median } \\
\hline $\begin{array}{l}\text { Family income } \\
\text { Nominal }(Y) \\
\text { Real }\left(Y^{*}\right) \\
\text { Per capita income }\end{array}$ & $\begin{array}{l}3324 \\
3324\end{array}$ & $\begin{array}{l}4369 . \\
8238 .\end{array}$ & $\begin{array}{r}5566 . \\
12974 .\end{array}$ & $\begin{array}{r}6381 . \\
17393 .\end{array}$ & $\begin{array}{r}6576 . \\
19438 .\end{array}$ & $\begin{array}{r}5326 . \\
11987 .\end{array}$ \\
\hline $\begin{array}{l}\text { Nominal }(Y) \\
\operatorname{Real}\left(Y^{*}\right) \\
n\end{array}$ & $\begin{array}{l}3324 . \\
3324 . \\
598\end{array}$ & $\begin{array}{l}2184 . \\
4119 . \\
2918\end{array}$ & $\begin{array}{l}1855 . \\
4324 . \\
1162\end{array}$ & $\begin{array}{l}1595 . \\
4348 . \\
1598\end{array}$ & $\begin{array}{l}1315 \\
3888 \\
1061\end{array}$ & $\begin{array}{l}1805 . \\
4125 . \\
7337\end{array}$ \\
\hline
\end{tabular}

equivalent size of a husband-wife family, $2 /(1+J)$. Here again the single person is taken as the numeraire.

To obtain estimates of equivalents for families of size 3.0 we proceed in the same manner. We chose to use only three-person households comprised of a husband-wife and child under age 18; the survey had 1,162 such families. For each person in the family we again used the demand equations estimated on single individuals to estimate what each family member would have spent on each of the six consumption items had he or she lived in a single person household. ${ }^{14}$ Summing these three estimated expenditures together gave us the estimated expenditure used in the numerator of equation (11), and the family's actual expenditure is used in the denominator to calculate the $\triangle P X_{i}$ for each item for each of the 1,162 husband-wife and child families. The median value of the dis-

\footnotetext{
${ }^{14}$ For children in the family we knew age brackets: $0-6,6-12,12-17$ (and for larger sized families $>18$ ). So we used piece-wise linear demand equations and assigned ages 3, 9, 15 (and 21 ) and assigned education levels $0,3,9$ (and 15), respectively. For the other characteristics of the child, we used father's characteristics (for race, city size, region, year) and for sex we used the value 0.5 .
}

tribution for each item is shown in the third column in Table 1. For each family we again estimated a $\Delta Y$ and its median value for these 1,162 families was 1.2699. Using the income and uncompensated price elasticities shown in Table 2, the $J$ 's shown in the fourth column of Table 1 were calculated. Again, all the prices are estimated to have fallen, with the decline for shelter and services relatively low and the biggest gains appearing to be in goods, transportation, and clothing. Here the average $J$ is 1.3384 , so the prices faced by these three-person families is estimated to be, on average, only 43 percent as high as the prices faced by the three single person households.

The same procedure has also been applied to the 1,598 four-person (husband-wife and two children) families and the results are shown in Table 1. Finally, the procedure was applied to 1,061 five-person (husbandwife and three children) families as well, and these results are also shown in Table 1. (The median values of $\Delta Y(4)$ and $\Delta Y(5)$ are 1.17 and 1.16 , respectively.)

Throughout, our estimates imply quite large gains in real terms from increases in family size. Real income (income in service flow equivalents with single persons as the 
numeraire) is substantially higher in large families than is nominal income. We estimate that $\$ 10,000$ nominal income to a family of five yields each of the five members the equivalent of $\$ 5,922$ in a single person equivalent dollars, or said differently, five can live together about as cheaply as 2.0 can live separately.

While Table 1 shows estimates of $J$ and equivalents by family size, we have taken a few steps toward estimating household-specific Js. We computed expenditure weights for specific family types defined over four age-of-head and five nominalincome groups and, using the $J_{i}$ estimates in Table 1, estimated a $J$ for each of the twenty family types. For smoothing purposes, for each family size we ran a separate weighted regression across these twenty $J \mathbf{s}$ and used those regressions to assign a $J$ to each household based on its size, age of head, and nominal income.

As our initial intention was to obtain comparable per capita income measures across families of different sizes, we can use these $J \mathbf{s}$ to do so. For each of the five family types discussed above (single persons,..., husband-wife and three children families), we assign a $J(J=0$ for the single persons, the numeraire). ${ }^{15}$ There are 7,337 such households in the $B L S$ data for which we then have two measures of family income:

$Y_{j}:$ the $j$ th household's actual nominal family income;

$Y_{j}^{*}=Y_{j}\left(1+J_{j}\right):$ the $j$ th household's real income equivalent.

Table 3 shows the mean and median $Y, Y^{*}$, and per capita $Y$ and $Y^{*}$ by family size. In single person equivalent dollars the real family income of larger families is quite high, but the real per capita income is comparatively constant across families of different sizes. As a result, the overall (median) per capita real income is substantially higher than the per capita nominal income among families of sizes 1 to $5(\$ 4,125$ compared to $\$ 1,805)$. Figure 1 shows the

\footnotetext{
${ }^{15}$ We have implicitly assumed homogeneity among single persons. We might have instead estimated the prices faced by single persons of various ages or sex and converted all singles into, say, 40-year-old male equivalents.
}

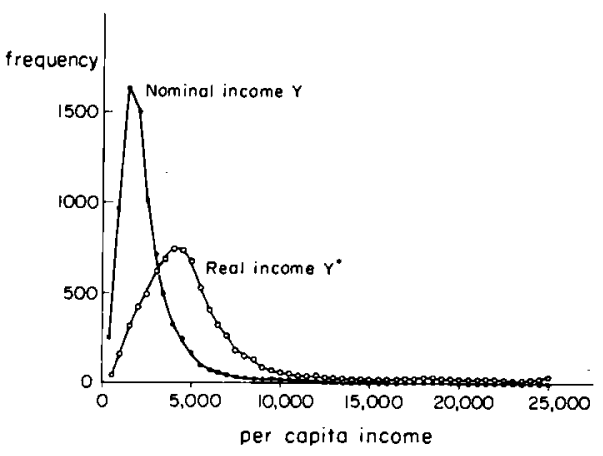

Figure 1. Distributions of Per Capita

Nominal Income $Y$ and Per Capita Real

INCOME $Y^{*}$ FOR 7,337 HoUSEHOLDS OF SIZE 1-5

frequency distribution of per capita $Y$ and $Y^{*}$, emphasizing the far more evenly distributed and larger mean value of the latter.

\section{Interpretation}

Our estimates suggest that a substantial adjustment in nominal income is necessary to reflect real (single person equivalent) income among families of different sizes. Scale economies, joint consumption of goods, and complementarity of goods and nonmarket time account for these substantial adjustments. Other studies have also emphasized these factors separately, as, for example, 1. A. Sirageldin's estimates of the distribution of real income including the market value of the household tasks performed by women, or Reuben Gronau's estimates of the housewife's contribution to full income.

We find that the adjustment in median income in our sample of families and unrelated individuals raises a median nominal per capita income of $\$ 1,805$ to $\$ 4,125$ in real dollars. One might ask what portion of that adjustment is capturing the nonworking wife's contribution to full income. Gronau's estimates (using information on time use from the Michigan Income Dynamics data) suggest that for married women of all ages and education levels combined, the nonmarket work done by women would raise income by about 60 percent (see his Table 7). Our numbers suggest a far greater adjust- 
Table 4-Equivalence SCales for Households of Size 1-5, Estimated BY Four TeChNiQues

\begin{tabular}{|c|c|c|c|c|}
\hline Household size & Naive & $B L S$ & Orshansky & $\mathbf{L M}$ \\
\hline \multicolumn{5}{|c|}{ Panel A Equivalence: 4 Person $=100$} \\
\hline $\begin{array}{l}1 \text { Person (male) } \\
2 \text { Person (husband-wife) } \\
3 \text { Person (husband-wife-child }<18 \text { ) } \\
4 \text { Person (husband-wife-2 children) } \\
5 \text { Person (husband-wife-3 children) }\end{array}$ & $\begin{array}{c}25 \\
50 \\
75 \\
100 \\
125\end{array}$ & $\begin{array}{l}36 \\
60 \\
82 \\
100 \\
116\end{array}$ & $\begin{array}{c}53 \\
67 \\
80 \\
100 \\
118\end{array}$ & $\begin{array}{l}68 \\
72 \\
88 \\
100 \\
115\end{array}$ \\
\hline \multicolumn{5}{|c|}{ Panel B Equivalence: 1 Person $=100$} \\
\hline $\begin{array}{l}1 \text { Person (male) } \\
2 \text { Person (husband-wife) } \\
3 \text { Person (husband-wife-child < 18) } \\
4 \text { Person (husband-wife-2 children) } \\
5 \text { Person (husband-wife-3 children) }\end{array}$ & $\begin{array}{l}100 \\
200 \\
300 \\
400 \\
500\end{array}$ & $\begin{array}{l}100 \\
167 \\
228 \\
278 \\
322\end{array}$ & $\begin{array}{l}100 \\
126 \\
151 \\
189 \\
223\end{array}$ & $\begin{array}{l}100 \\
106 \\
128 \\
147 \\
169\end{array}$ \\
\hline
\end{tabular}

ment, but ours reflect not only this nonmarket time effect but also scale and joint consumption effects. Our estimate for each family of $\left(Y_{m}+Y_{f}\right)$, discussed above and used in estimating $\Delta Y$ for each household size separately, indicates the nominal income the family would have received if both spouses allocated their time as comparable single persons do. Thus we can consider $Y^{\prime}=Y_{m}^{\prime}+Y_{f}^{\prime}$ as a crude measure of the labor supply-adjusted family income. If we compare its per capita value with the per capita observed nominal income $(Y)$ and our estimate of the per capita real income $\left(Y^{*}\right)$, we find:

\begin{tabular}{lrr} 
& \multicolumn{2}{c}{ Per Capita income } \\
\cline { 2 - 3 } & Median & \multicolumn{1}{c}{ Mean } \\
\cline { 2 - 3 } Nominal income $(Y):$ & $\$ 1,805$ & $\$ 2,216$ \\
Labor-supply adjusted & 2,270 & 2,480 \\
$\quad$ income $\left(Y^{\prime}\right):$ & & \\
Real income $\left(Y^{\star}\right):$ & 4,125 & 4,601
\end{tabular}

The adjustment for labor supply accounts for only a small portion of the adjustment from nominal to real income. The remainder may be scale effects, joint consumption effects, ṕossibly complementary effects of one spouse on the other, or other effects. It does not appear to be the case that most of our estimated adjustment of $Y$ to $Y^{*}$ is simply an adjustment for unearned income of married women.

Another way to isolate the effects of nonmarket time is to look separately at the implied price effect (or $J$ ) for families with two employed adults and those with only one employed adult. We would expect a higher $J$ in the families with only one employed adult, reflecting the greater flow of services $(S)$ per dollar of market goods $(X)$ as discussed above. We selected, from our sample of 2,918 two-person families, two subsets: (a) a group of 1,043 comprised of all those couples for which the head was employed full time and the spouse was not employed during the year; (b) a group of 362 comprised of all those couples for which both the head and the spouse were employed full time. On the basis of the observed $\triangle P X_{i}$ and $\Delta Y$ for these two subgroups separately, the $J$ for the one-earner families was 0.83 , the $J$ for the two-fulltime-earner families was 0.75 . While the difference is in the expected direction, the $J$ for the two-earner families is higher than might be expected. This suggestive evidence corroborates the conclusion of the previous

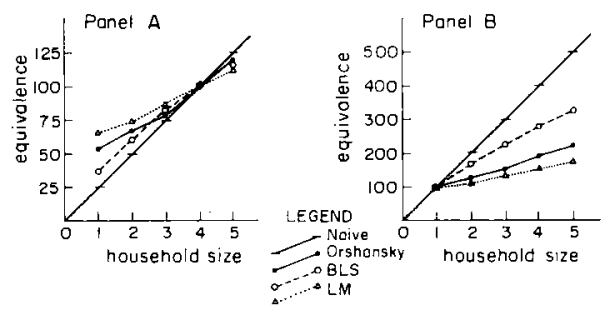

Figure 2. Equivalence Scales for Households of Size 1-5 by Four Techniques 
Table 5-Estmated Percentage in Poverty

(1960-1961 SAMPLE; IN PERCENTAGE)

\begin{tabular}{|c|c|c|c|c|c|c|}
\hline \multirow[b]{3}{*}{$\begin{array}{l}\text { Orshansky scale: } \\
\text { LM scale: } \\
n\end{array}$} & \multicolumn{6}{|c|}{ Age of head } \\
\hline & \multicolumn{2}{|c|}{$<35$} & $35-64$ & $>65$ & \multicolumn{2}{|c|}{ Total } \\
\hline & \multicolumn{2}{|c|}{$\begin{array}{c}6.7 \\
7.7 \\
(1762)\end{array}$} & $\begin{array}{c}8.9 \\
10.1 \\
(4365)\end{array}$ & \multirow{2}{*}{$\begin{array}{c}25.0 \\
33.7 \\
(1210) \\
z e\end{array}$} & \multicolumn{2}{|c|}{$\begin{array}{r}11.0 \\
13.4 \\
(7337)\end{array}$} \\
\hline & \multicolumn{5}{|c|}{ Family size } & \\
\hline & 1 & 2 & 3 & 4 & 5 & Total \\
\hline $\begin{array}{l}\text { Orshansky scale: } \\
\text { LM scale: } \\
n\end{array}$ & $\begin{array}{l}17.6 \\
25.3 \\
(598)\end{array}$ & $\begin{array}{c}14.3 \\
18.4 \\
(2918)\end{array}$ & $\begin{array}{c}6.9 \\
8.2 \\
(1162)\end{array}$ & $\begin{array}{c}6.7 \\
6.9 \\
(1598)\end{array}$ & $\begin{array}{c}9.3 \\
8.7 \\
(1061)\end{array}$ & $\begin{array}{r}11.0 \\
13.4 \\
(7337)\end{array}$ \\
\hline
\end{tabular}

paragraph that much of the gain in real income comes from sources other than the differences in labor supply.

Another real income adjustment found frequently in the literature is the equivalence scale for households of different sizes and age structures. Perhaps the two best known equivalence scales are the $B L S$ and the Orshansky scales. The $B L S$ scale is used in their Family Budget series and derived by inferences based on the notion that families who spend the same proportion of their disposable income on an income-inelastic item such as food act as if they have the same real income. The Orshansky scale is used in constructing poverty levels for families of various sizes, and derived from estimates of the costs of purchasing nutritionally adequate diets for families of different sizes. As our Table 1 indicates the per capita single person equivalent income of $\$ 10,000$ in nominal family income, we can use these figures to derive a comparable equivalence scale. That is, $Y_{0}\left(\left(1+J_{j}\right) / j\right) /$ $\left(\left(1+J_{k}\right) / k\right)$ would be the equivalent nominal income in $k$-person household units of the nominal income of $Y_{0}$ in $j$-person households. ${ }^{16}$ Table 4 shows these equivalence scales for $B L S$, Orshansky, and LM (Lazear-Michael) estimates. For comparison the first column shows the numbers for the

\footnotetext{
${ }^{16}$ We convert nominal income $Y_{0}$ in a $j$-person household into real per capita income in single person household units as $Y_{0}\left(1+J_{j}\right) / j \equiv Y_{j}$. This is converted to per capita income units of a $k$-person household as $\left(Y_{j} /\left(1+J_{k}\right)\right)$. Or to convert to family income for that household, multiply the expression by $k$ to obtain $\left(Y_{j} /\left(1+J_{k}\right)\right) k$.
}

naive assumption of complete absence of scale or other effects. Panel $A$ indexes these equivalence scales based on a family of size four and since the choice of a numeraire can affect the apparent differences, Panel $B$ shows the indices based on a single person equivalence. Also see Figure 2.

Given the tremendously different algorithms used in constructing these three equivalence scales, it is interesting to note how similar they are, at least among families of sizes 2 through 5. Large differences exist, however, in going to single person households, where the LM estimate suggests far more "scale" economy than the other (especially the $B L S$ ) estimates. This difference for single person households is especially important for comparisons of equivalent real income over time, as the proportion of single person households has risen considerably in the U.S. population in the postwar period.

One other comparison which can be performed with our data is to identify the differences in the poverty population when that population is designated by the official equivalence scales and by the LM equivalence scales. We calculated the two poverty benchmarks for each of the 7,337 households in our sample and determined which households were "in poverty" by each definition. The official level of poverty income for a family of four composed of husband, wife, and two children in 1960 was $\$ 3,022$ and in $1961, \$ 3,054$. Using the Orshansky equivalence scales in Panel $A$ of Table 4 the poverty level for the other types of households are easily computed (for example, for 
a single person under age 65 in 1960 , the poverty level was $(.53)(\$ 3,022$. $)=\$ 1,602)$. Likewise, using the LM estimates of equivalence the poverty level comparable to $\$ 3,022$ for a family of four is easily computed (for example, for a single person under 65 in $1960,(.68)(\$ 3,022)=.\$ 2,055)$.

The percentages in poverty, by age of head, and by family size, using the Orshansky scale and the LM scale are shown in Table 5 . While the overall percentage is only moderately higher with the LM equivalence scales, a substantially higher fraction of single persons or older persons is estimated as "in poverty" using the LM scales. Given the substantial "scale" effects between single person and four-person households, if $\$ 3,000$ is the benchmark for poverty for the four-person family the single person requires a relatively larger amount to be as well off.

There are other comparisons and modifications which might be made. We hope in subsequent work to use more recent data, containing more complete information on each family member's demographic characteristics. Our procedure could easily be extended to families of sizes greater than five and to different family structures (for example, female-headed families). Relaxation of the assumed homogeneity of all single person households in terms of $J_{\mathrm{s}}$ seems an appropriate extension as does some additional checking on the sensitivity of our estimates to the price elasticities which were employed here. ${ }^{17} \mathrm{We}$ suggest our procedure for estimating per capita income equivalence among families of different sizes has among its other appealing properties the fact that it is embedded in a standard economic theory of demand. We use changes in expenditures plus price elasticities to infer changes in prices from which real (price deflated) levels of income can be inferred.

\footnotetext{
${ }^{17}$ Substantial sensitivity analysis has been done. In addition to the set of estimates described in this paper, three other sets of estimates have been made. Elasticity
}

Table A1-Details about The Six Expenditure CATEgories; 1960-61 BLS, CES (Weights for two-person families)

\begin{tabular}{|c|c|c|c|}
\hline & $\begin{array}{c}\text { Category } \\
\text { Percent }\end{array}$ & $\begin{array}{c}\text { Total } \\
\text { Percent }\end{array}$ & Dollars \\
\hline Food & 100.0 & 25.9 & 1079 . \\
\hline $\begin{array}{l}\text { Food at home } \\
\text { Food away } \\
\text { Alcohol }\end{array}$ & $\begin{array}{r}75.5 \\
16.9 \\
7.6\end{array}$ & & \\
\hline Clothing & 100.0 & 8.4 & 350. \\
\hline Transportation & 100.0 & 16.8 & 699. \\
\hline $\begin{array}{l}\text { Auto operation } \\
\text { Car purchase } \\
\text { Public transportation }\end{array}$ & $\begin{array}{l}51.0 \\
37.6 \\
11.4\end{array}$ & & \\
\hline Goods & 100.0 & 13.0 & 540. \\
\hline $\begin{array}{l}\text { Household furnishings } \\
\text { and equipment } \\
\text { Recreation } \\
\text { Reading } \\
\text { Vacation homes } \\
\text { Lodging away from home } \\
\text { Tobacco }\end{array}$ & $\begin{array}{r}42.8 \\
\\
27.2 \\
7.8 \\
1.3 \\
5.1 \\
15.8\end{array}$ & & \\
\hline Services & 100.0 & 11.3 & 469. \\
\hline $\begin{array}{l}\text { Medical care } \\
\text { Personal care } \\
\text { Education }\end{array}$ & $\begin{array}{r}71.5 \\
26.4 \\
2.1\end{array}$ & & \\
\hline Shelter & 100.0 & 24.6 & 1022. \\
\hline $\begin{array}{l}\text { Utilities } \\
\text { Household operation } \\
\text { Rent or owner's expenses }\end{array}$ & $\begin{array}{l}23.3 \\
24.3 \\
52.4\end{array}$ & & \\
\hline
\end{tabular}

estimates from the Abbott-Ashenfelter system, augmented to include leisure as a separate item, were used directly in one set of estimates (estimate $A$ ). Using the own-price elasticities but assuming all cross elasticities to be zero and setting $\Delta Y=0$, a second set of $J_{i}$ 's were computed (estimate $B$ ). Similarly, using a somewhat different set of own- and cross-price elasticities (for example, the elasticity of services with respect to the price of food $=-0.095$ in estimate $A$ but $=-0.149$ in estimate $C$ ) and a slightly different set of $\eta_{X_{i}, Y}$, another set of $J_{i}$ 's were estimated (estimate $C$ ). The estimated $J$ for families of size 2 through 5 from these three sets of estimates were

Text estimates: $.89 ; 1.34 ; 1.73 ; 1.96$

Estimate $A: .84 ; 1.30 ; 1.67 ; 1.92$

Estimate $B: .76 ; 1.23 ; 1.45 ; 1.68$

Estimate $C: .83 ; 1.26 ; 1.63 ; 1.89$

So while there are not inconsequential differences and the estimates reported in the text are somewhat larger than the others, rather large differences in the initial elasticities yield only modestly different average $J_{\mathrm{s}}$. We think this comparison implies a substantial degree of robustness in our estimates. 
TAble A2-Reduced-Form Expendture Equations; Sinale Consumers;

1960-61 BLS, CES

\begin{tabular}{|c|c|c|c|c|c|c|c|}
\hline Variable & Food & Clothing & Transport & Shelter & Goods & Services & $\begin{array}{l}\text { Sample } \\
\text { Mean }\end{array}$ \\
\hline Intercept & $\begin{array}{r}149.84 \\
(0.57)\end{array}$ & $\begin{array}{r}308.000 \\
(2.98)\end{array}$ & $\begin{array}{c}-204.05 \\
(-0.57)\end{array}$ & $\begin{array}{c}-229.78 \\
(-0.97)\end{array}$ & $\begin{array}{l}78.23 \\
(0.48)\end{array}$ & $\begin{array}{l}66.92 \\
(0.55)\end{array}$ & 1.00 \\
\hline $\begin{array}{l}\text { Sex } \\
\quad 1=\text { male }\end{array}$ & $\begin{array}{r}394.46 \\
(8.18)\end{array}$ & $\begin{array}{l}-96.31 \\
(-5.11)\end{array}$ & $\begin{array}{c}195.02 \\
(3.01)\end{array}$ & $\begin{array}{l}-21.41 \\
(-0.50)\end{array}$ & $\begin{array}{r}126.47 \\
(4.27)\end{array}$ & $\begin{array}{l}-77.48 \\
(-3.51)\end{array}$ & $\begin{array}{c}0.46 \\
(0.50)\end{array}$ \\
\hline $\begin{array}{l}\text { Year } \\
\qquad 1=1961\end{array}$ & $\begin{array}{l}-98.99 \\
(-2.14)\end{array}$ & $\begin{array}{c}24.00 \\
(1.33)\end{array}$ & $\begin{array}{c}-7.42 \\
(-0.12)\end{array}$ & $\begin{array}{l}17.64 \\
(0.42)\end{array}$ & $\begin{array}{c}27.93 \\
(0.98)\end{array}$ & $\begin{array}{l}21.04 \\
(0.99)\end{array}$ & $\begin{array}{c}0.57 \\
(0.50)\end{array}$ \\
\hline North East & $\begin{array}{c}35.83 \\
(0.53)\end{array}$ & $\begin{array}{c}0.02 \\
(0.01)\end{array}$ & $\begin{array}{l}12.06 \\
(0.13)\end{array}$ & $\begin{array}{l}72.57 \\
(1.21)\end{array}$ & $\begin{array}{r}106.32 \\
(2.54)\end{array}$ & $\begin{array}{l}-65.05 \\
(-2.08)\end{array}$ & $\begin{array}{c}0.28 \\
(0.45)\end{array}$ \\
\hline N. Central & $\begin{array}{r}-138.15 \\
(-2.04)\end{array}$ & $\begin{array}{l}-67.03 \\
(-2.52)\end{array}$ & $\begin{array}{r}-153.98 \\
(-1.69)\end{array}$ & $\begin{array}{r}-117.47 \\
(-1.93)\end{array}$ & $\begin{array}{l}25.80 \\
(0.62)\end{array}$ & $\begin{array}{l}-85.03 \\
(-2.74)\end{array}$ & $\begin{array}{c}0.29 \\
(0.45)\end{array}$ \\
\hline South & $\begin{array}{c}-192.98 \\
(-2.76)\end{array}$ & $\begin{array}{l}10.83 \\
(0.40)\end{array}$ & $\begin{array}{l}-92.61 \\
(-0.99)\end{array}$ & $\begin{array}{r}-119.33 \\
(-1.93)\end{array}$ & $\begin{array}{l}55.76 \\
(1.30)\end{array}$ & $\begin{array}{l}-69.86 \\
(-2.18)\end{array}$ & $\begin{array}{c}0.24 \\
(0.43)\end{array}$ \\
\hline Central City & $\begin{array}{r}133.62 \\
(2.74)\end{array}$ & $\begin{array}{l}21.77 \\
(1.14)\end{array}$ & $\begin{array}{c}-110.87 \\
(-1.70)\end{array}$ & $\begin{array}{r}179.03 \\
(4.04)\end{array}$ & $\begin{array}{r}102.12 \\
(3.41)\end{array}$ & $\begin{array}{c}60.03 \\
(2.69)\end{array}$ & $\begin{array}{c}0.48 \\
(0.50)\end{array}$ \\
\hline Large City & $\begin{array}{l}63.84 \\
(0.59)\end{array}$ & $\begin{array}{l}43.20 \\
(1.03)\end{array}$ & $\begin{array}{c}172.78 \\
(1.20)\end{array}$ & $\begin{array}{c}194.20 \\
(2.02)\end{array}$ & $\begin{array}{l}61.12 \\
(0.93)\end{array}$ & $\begin{array}{l}-35.49 \\
(-0.72)\end{array}$ & $\begin{array}{c}0.05 \\
(0.22)\end{array}$ \\
\hline $\begin{array}{l}\text { Race } \\
\qquad 1 \text { = white }\end{array}$ & $\begin{array}{r}161.66 \\
(2.11)\end{array}$ & $\begin{array}{l}48.77 \\
(1.63)\end{array}$ & $\begin{array}{l}78.45 \\
(0.76)\end{array}$ & $\begin{array}{r}137.78 \\
(2.11)\end{array}$ & $\begin{array}{r}106.54 \\
(2.26)\end{array}$ & $\begin{array}{c}49.56 \\
(1.41)\end{array}$ & $\begin{array}{c}0.89 \\
(0.31)\end{array}$ \\
\hline Age $<25$ & $\begin{array}{c}4.90 \\
(0.48)\end{array}$ & $\begin{array}{c}-4.86 \\
(-1.21)\end{array}$ & $\begin{array}{l}14.14 \\
(1.02)\end{array}$ & $\begin{array}{c}6.34 \\
(0.70)\end{array}$ & $\begin{array}{l}-12.21 \\
(-1.93)\end{array}$ & $\begin{array}{r}-0.06 \\
(0.01)\end{array}$ & $\begin{array}{l}22.44 \\
(2.08)\end{array}$ \\
\hline Age 25-34 & $\begin{array}{c}6.51 \\
(0.84)\end{array}$ & $\begin{array}{c}-3.30 \\
(-1.09)\end{array}$ & $\begin{array}{l}12.24 \\
(1.17)\end{array}$ & $\begin{array}{c}8.72 \\
(1.26)\end{array}$ & $\begin{array}{c}-4.99 \\
(-1.04)\end{array}$ & $\begin{array}{c}1.21 \\
(6.34)\end{array}$ & $\begin{array}{l}29.56 \\
(2.73)\end{array}$ \\
\hline Age 35-54 & $\begin{array}{c}6.64 \\
(1.36)\end{array}$ & $\begin{array}{c}-3.79 \\
(-2.00)\end{array}$ & $\begin{array}{c}4.10 \\
(0.62)\end{array}$ & $\begin{array}{c}9.70 \\
(2.19)\end{array}$ & $\begin{array}{c}-5.01 \\
(-1.66)\end{array}$ & $\begin{array}{c}0.81 \\
(0.36)\end{array}$ & $\begin{array}{l}46.22 \\
(6.32)\end{array}$ \\
\hline Age 55-64 & $\begin{array}{c}1.71 \\
(0.44)\end{array}$ & $\begin{array}{c}-4.54 \\
(-3.00)\end{array}$ & $\begin{array}{c}0.80 \\
(0.15)\end{array}$ & $\begin{array}{c}5.68 \\
(1.61)\end{array}$ & $\begin{array}{l}-5.02 \\
(-2.10)\end{array}$ & $\begin{array}{c}0.79 \\
(0.44)\end{array}$ & $\begin{array}{l}60.44 \\
(2.49)\end{array}$ \\
\hline Age $>65$ & $\begin{array}{c}-0.46 \\
(-0.14)\end{array}$ & $\begin{array}{c}-4.87 \\
(-3.89)\end{array}$ & $\begin{array}{c}-0.99 \\
(-0.23)\end{array}$ & $\begin{array}{c}5.63 \\
(1.95)\end{array}$ & $\begin{array}{c}-5.40 \\
(-2.74)\end{array}$ & $\begin{array}{c}0.57 \\
(0.39)\end{array}$ & $\begin{array}{l}72.43 \\
(5.53)\end{array}$ \\
\hline Education & $\begin{array}{l}21.10 \\
(3.34)\end{array}$ & $\begin{array}{l}14.94 \\
(6.05)\end{array}$ & $\begin{array}{l}39.62 \\
(4.67)\end{array}$ & $\begin{array}{l}43.52 \\
(7.40)\end{array}$ & $\begin{array}{c}21.90 \\
(5.65)\end{array}$ & $\begin{array}{l}15.29 \\
(5.29)\end{array}$ & $\begin{array}{l}11.29 \\
(4.10)\end{array}$ \\
\hline $\begin{array}{l}R^{2} \\
\text { Mean } \\
S . D . \\
n\end{array}$ & $\begin{array}{c}0.22 \\
799.30 \\
(604.63) \\
598\end{array}$ & $\begin{array}{c}0.34 \\
280.15 \\
(257.52) \\
598\end{array}$ & $\begin{array}{c}0.14 \\
451.28 \\
(773.89) \\
598\end{array}$ & $\begin{array}{c}0.25 \\
779.56 \\
(477.53) \\
435\end{array}$ & $\begin{array}{c}0.21 \\
328.62 \\
(369.85) \\
598\end{array}$ & $\begin{array}{c}0.14 \\
260.46 \\
(263.46) \\
598\end{array}$ & \\
\hline
\end{tabular}


Table A3-OLS Regressions on InCOMe, Single Consumers, by SeX

\begin{tabular}{|c|c|c|c|c|}
\hline & \multirow[b]{2}{*}{ Male Income } & \multirow[b]{2}{*}{ Female Income } & \multicolumn{2}{|c|}{ Sample Mean } \\
\hline & & & Men & Women \\
\hline Constant & $\begin{array}{r}-924.13 \\
(-0.66)\end{array}$ & $\begin{array}{r}-5477.61 \\
(-6.48)\end{array}$ & 1.00 & 1.00 \\
\hline $\begin{array}{l}\text { Year } \\
\qquad 1=1961\end{array}$ & $\begin{array}{c}-155.96 \\
(-0.51)\end{array}$ & $\begin{array}{r}423.07 \\
(2.39)\end{array}$ & $\begin{array}{c}0.60 \\
(0.49)\end{array}$ & $\begin{array}{c}0.54 \\
(0.50)\end{array}$ \\
\hline North East & $\begin{array}{r}412.87 \\
(0.95)\end{array}$ & $\begin{array}{r}-166.24 \\
(-0.61)\end{array}$ & $\begin{array}{c}0.26 \\
(0.44)\end{array}$ & $\begin{array}{r}0.30 \\
(0.46)\end{array}$ \\
\hline North Central & $\begin{array}{c}-370.95 \\
(-0.89)\end{array}$ & $\begin{array}{r}-452.18 \\
(-1.63)\end{array}$ & $\begin{array}{c}0.31 \\
(0.46)\end{array}$ & $\begin{array}{r}0.28 \\
(0.45)\end{array}$ \\
\hline South & $\begin{array}{r}-509.85 \\
(-1.15)\end{array}$ & $\begin{array}{r}-295.20 \\
(-1.06)\end{array}$ & $\begin{array}{c}0.22 \\
(0.41)\end{array}$ & $\begin{array}{r}0.26 \\
(0.44)\end{array}$ \\
\hline Central City & $\begin{array}{c}8.72 \\
(0.03)\end{array}$ & $\begin{array}{c}564.01 \\
(3.09)\end{array}$ & $\begin{array}{c}0.44 \\
(0.50)\end{array}$ & $\begin{array}{l}0.52 \\
(0.50)\end{array}$ \\
\hline Large City & $\begin{array}{r}2216.00 \\
(3.13)\end{array}$ & $\begin{array}{r}376.80 \\
(0.92)\end{array}$ & $\begin{array}{c}0.05 \\
(0.21)\end{array}$ & $\begin{array}{l}0.05 \\
(0.22)\end{array}$ \\
\hline $\begin{array}{l}\text { Race } \\
\qquad \text { = white }\end{array}$ & $\begin{array}{r}409.78 \\
(0.91)\end{array}$ & $\begin{array}{c}1152.73 \\
(3.28)\end{array}$ & $\begin{array}{c}0.85 \\
(0.36)\end{array}$ & $\begin{array}{c}0.93 \\
(0.25)\end{array}$ \\
\hline Age & $\begin{array}{r}128.34 \\
(2.44)\end{array}$ & $\begin{array}{c}210.02 \\
(7.59)\end{array}$ & $\begin{array}{c}45.00 \\
(17.74)\end{array}$ & $\begin{array}{r}49.52 \\
(18.74)\end{array}$ \\
\hline $\mathrm{Age}^{2}$ & $\begin{array}{c}-1.54 \\
(-2.89)\end{array}$ & $\begin{array}{c}-2.17 \\
(-7.84)\end{array}$ & $\begin{array}{c}2336.73 \\
(1700.59)\end{array}$ & $\begin{array}{r}2803.07 \\
(1871.60)\end{array}$ \\
\hline Education & $\begin{array}{r}205.82 \\
(4.89)\end{array}$ & $\begin{array}{l}269.87 \\
(11.00)\end{array}$ & $\begin{array}{l}10.20 \\
(4.34)\end{array}$ & $\begin{array}{l}12.21 \\
(3.64)\end{array}$ \\
\hline$R^{2}$ & 0.26 & 0.43 & & \\
\hline $\begin{array}{l}n \\
\text { Mean }\end{array}$ & $\begin{array}{c}275 \\
3578.70\end{array}$ & $\begin{array}{c}323 \\
3505.31\end{array}$ & & \\
\hline S.D. & 2707.08 & 1996.81 & & \\
\hline
\end{tabular}


Table A4-Percentage of Famides nn Poverty (1960-61 sample), using Orshansky and LM Equtvalence SCales, by Age of Head and Famil Composition

\begin{tabular}{|c|c|c|c|c|}
\hline \multirow[b]{2}{*}{ Family Composition } & \multirow[b]{2}{*}{$<35$} & \multicolumn{2}{|c|}{ Age of Head } & \multirow[b]{2}{*}{ All ages } \\
\hline & & $35-64$ & $65+$ & \\
\hline \multicolumn{5}{|l|}{ Orshansky Scale: } \\
\hline$\overline{1 \text { Person }}$ & 4.0 & 15.7 & 41.7 & 17.6 \\
\hline 2 Persons & 2.8 & 11.0 & 22.6 & 14.3 \\
\hline 3 Persons & 6.6 & 6.5 & $29.4^{2}$ & 6.9 \\
\hline with child $<6$ & 7.2 & 4.2 & - & 6.6 \\
\hline with child age 6- 17 & 3.2 & 6.9 & $29.4^{4}$ & 7.1 \\
\hline 4 Persons & 7.4 & 6.0 & $41.7^{2}$ & 6.7 \\
\hline all children $<6$ & 7.4 & 8.6 & - & 7.6 \\
\hline with children $>6$ & 7.3 & 5.8 & $41.7^{\mathrm{a}}$ & 6.4 \\
\hline 5 Persons & 10.7 & $8.4^{2}$ & 33.3" & 9.3 \\
\hline with children $<6$ & 12.2 & 27.3 & - & 13.8 \\
\hline all children > 6 & 10.1 & 8.1 & $33.3^{2}$ & 8.8 \\
\hline Total & 6.7 & 8.9 & 25.0 & 11.0 \\
\hline \multicolumn{5}{|l|}{ Lazear-Michael scale: } \\
\hline 1 Person & 9.0 & 22.8 & 54.6 & 25.3 \\
\hline 2 Persons & 3.9 & 12.7 & 31.0 & 18.4 \\
\hline 3 Persons & 8.0 & 7.8 & $29.4^{2}$ & 8.2 \\
\hline with child < 6 & 8.8 & 4.2 & - & 7.9 \\
\hline with child 6-17 & 3.2 & B.3 & $29.4^{a}$ & 8.4 \\
\hline 4 Persons & 7.9 & 6.0 & $50.0^{2}$ & 6.9 \\
\hline all children $<6$ & 8.0 & 8.6 & - & 8.1 \\
\hline with children $>6$ & 7.8 & 5.8 & $50.0^{\circ}$ & 6.6 \\
\hline 5 Persons & 9.5 & $8.0^{2}$ & $33.3^{2}$ & 8.7 \\
\hline with children $<6$ & 12.2 & 27.3 & - & 13.8 \\
\hline all children $>6$ & 8.4 & 7.7 & $33.3^{3}$ & 8.1 \\
\hline Total & 7.7 & 10.1 & 33.7 & 13.4 \\
\hline
\end{tabular}

"Cell contains less than twenty families.

\section{REFERENCES}

M. Abbott and O. Ashenfelter, "Labour Supply, Commodity Demand, and the Allocation of Time," Rev. Econ. Stud., Oct. 1976, 43, 389-411. (Estimation corrected Oct. 1977.)

A. P. Barten, "Family Composition, Prices and Expenditure Patterns," in P. E. Hart et al., eds., Econometric Analysis for $\mathrm{Na}$ tional Economic Planning, London 1964.

G. S. Becker, "A Theory of Social Interactions," J. Polit. Econ., Dec. 1974, 82, 1063-93.

E. Engel, "Die Lebenskosten belgischer Arbeiter-Familien Fruher und jetzt," Int. Statist. Inst. Bull., No. 9, 1895.

T. J. Espenshade, "The Cost of Children in Urban U.S.," Population Monog. Series No. 14, Inst. Int. Stud., Univ. CaliforniaBerkeley 1973.

R. Gronau, "Home Production-A Forgotten Industry ,"Rev. Econ. Statist., forthcoming..

A. M. Henderson, "The Cost of Children, Part
I, " Pop. Stud., Sept. 1949, 3, 130-50; "Parts II, III," Dec. 1950, 4, 267-98.

B. S. Mahoney, The Measure of Poverty, Poverty Studies Task Force, H. E. W., Washington 1976.

J. Mincer, "Family Migration Decisions," $J$. Polit. Econ, Oct. 1978, 86, 749-773.

J. Muellbauer, "Testing the Barten Model of Household Composition Effects and the Cost of Children," Econ. J., Sept. 1977, 87, 460-487.

M. Orshansky, "Table $11, "$ in B. S. Mahoney, ed., The Measure of Poverty, Washington 1976.

S. J. Prais and Hendrick S. Houthakker, The Analysis of Family Budgets, London 1955.

P. A. Samuelson, "Social Indifference Curves," Quart. J. Econ., Feb. 1956, 70, 1-22.

I. A. Sirngeldin, "Nonmarket Components of National Income," Inst. Soc. Res., Univ. Michigan, Ann Arbor 1969.

U.S. Bureau of Labor Statistics (BLS), Survey of Consumer Expenditures 1960-61, Washington 1966. 


\title{
Sources of Quality Change in Labor Input
}

\author{
By Peter Chinloy*
}

Labor input is the product of total hours worked and average labor quality per hour. Labor quality accounts for the level of skill provided per hour worked, including educational and demographic factors. Change in labor quality can be expressed as the sum of main effects associated with these factors and interactive effects of various orders yielding a growth accounting equation for labor input. This is applied to a classification of total hours worked by sex, class of worker (employee or self-employed), age, education, and occupation for the U.S. private domestic economy 1947-74. The main conclusions are:

(a) The contribution to labor input growth of education is 0.6 percent per annum. This effect is reduced by one-half if interactive effects are included, as the educated become younger and more female. The main effect for education declines by over one-fifth between 1959-63 and 1971-74, which may indicate a decline in the contribution of education to U.S. productivity growth.

(b) A linear logarithmic quality change estimate excluding interactions overstates the growth of labor quality by one-half. ${ }^{1}$ This suggests that the contribution of education and experience to economic growth, for example, may not be measured by multiplying together indices of each factor. The overstatement amounts to 0.3 percent per annum, which at a labor share of two-thirds, overstates the contribution of labor input to output growth by 0.2 percent per annum.

(c) The main effect of the substantial increase in relative share of women in total hours is negative. The inclusion of interac-

\footnotetext{
-University of British Columbia. I am grateful to William Barger, Erwin Diewert, Richard Freeman, Frank Gollop, Robert Hall, and Dale Jorgenson for their substantial contributions to this work.

${ }^{1}$ Richard Nelson has argued that experienced growth may involve interaction effects as well as main effects of factors.
}

tive effects reduces this effect from -.15 to -.07 percent per annum, accounting for the skill composition of women.

(d) A watershed develops in the 1959-63 period in assessing the relative importance of total hours and labor quality as sources of labor input growth. Over $1947-59$, labor quality is relatively dominant, accounting for over three-quarters of labor input growth of about 1.3 percent per annum. For 1963-74, labor input increases in growth to 1.9 percent annually, but quality change accounts for only one-tenth. Quality change in the U.S. labor market almost disappears, declining from 1.12 percent for 1947-52 to 0.12 percent over 1971-74.

\section{Labor Input Indexing}

The indexing of labor input commences with a production function aggregating nonlabor services and the services provided by different types of labor. An aggregate of labor input exists if types of labor are weakly separable from nonlabor inputs. I assume the labor market is efficient, and types of labor paid marginal products. Labor input can increase even if total hours worked are constant. Suppose there are two types of labor, skilled and unskilled. The former receive above average wages, and both work the same hours. If an unskilled worker becomes skilled, total hours remain unchanged, but labor input increases since the marginal product of this worker increases. The objective is to quantify these changes in labor input and associate them with characteristics of employment.

The production function, separable between labor and nonlabor inputs, is at time $\mathrm{t}$ :

$$
y_{1}=g\left(z_{1}, x_{1 \mathfrak{v}}, \ldots, x_{p v}, t\right)
$$

where $y_{\mathrm{t}}$ represents output, $z_{\mathrm{t}}$ labor input, 